Authors' Contribution:

A Study Design

B Data Collection

C Statistical Analysis

D Data Interpretation

E Manuscript Preparation

F Literature Search

G Funds Collection

\section{The set of test tasks assessing special physical fitness of 17-year-old soccer players}

\author{
Andrzej Szwarc ${ }^{1}$ ABDEFG, Bartosz Dolanski1 ${ }^{1 \text { BCDEFG, }}$ \\ Patrycja Lipinska2 BCDEG \\ Gdansk University of Physical Education and Sport in Gdansk, Poland \\ ${ }^{1}$ Department of Team Games and Martial Arts \\ 2 Department of Information Technology and Statistics
}

\title{
abstract
}

Background: The objective of the research was to work out the set of test tasks assessing special physical fitness of 17-year-old soccer players.

Material/Methods: At first, on the basis of the analysis of the said issue in literature and the authors' own coaching experience, 13 test tasks were selected. Next, reliability and accuracy of the chosen test tasks were examined on the group of 16 athletes from the Centre of Sports training for youth in Gdansk. The reliability was assessed by the test-re-test method and the accuracy according to a criterion of internal accuracy tests.

Except for one task, all efficiency tests met scientific requirements for motor tests. Finally, with the use of statistical analysis (linear regression equation, Hellwig's algorithm of the optimal choice of explaining variables), four tests implementing most information for the assessment of game-play were chosen.

Results: A four-task set of tests assessing selected components of physical fitness reflected $86.7 \%$ of the game-play of young competitors.

Conclusions: Results of special physical fitness tests should be treated as important information about young athletes' special physical efficiency, closely interdependent with the effectiveness of their activity in a classified game-play, but only when the tests themselves have previously been scientifically proved.

Key words: soccer, youth, fitness tests, reliability, accuracy.

\section{article details}

Article statistics: Word count: 2450; Tables: 4; Figures: 0; References: 21

Received: January 2015; Accepted: February 2015; Published: March 2015

Full-text PDF: http://www.balticsportscience.com

Copyright Gdansk University of Physical Education and Sport, Poland

Indexation: Celdes, CNKI Scholar (China National Knowledge Infrastructure), CNPIEC, De Gruyter - IBR (International Bibliography of Reviews of Scholarly Literature in the Humanities and Social Sciences), De Gruyter - IBZ (International Bibliography of Periodical Literature in the Humanities and Social Sciences), DOAJ, EBSCO - Centra \& Eastern European Academic Source, EBSCO - SPORTDiscus, EBSCO Discovery Service, Google Scholar, Index Copernicus, J-Gate, Naviga (Softweco, Primo Central (Ex-Libris), ProQuest - Family Health, ProQuest - Health \& Medical Complete, ProQuest - Illustrata: Health Sciences, ProQuest - Nursing \& Allied Health Source, Summon (Serials Solutions/ProQuest, TDOne (TDNet), Ulrich's Periodicals Directory/ulrichsweb, WorldCat (OCLC)

Funding: Authors' own sources. No external funding was received

Conflict of interests: Authors have declared that no competing interest exits

Corresponding author: Bartosz Dolanski, PhD, Gdansk University of Physical Education and Sport. Gorskiego St. 1, 80-336 Gdansk, Poland, Phone: +48603907737, e-mail: dolan@awf.gda.pl

Open Access License: This is an open access article distributed under the terms of the Creative Commons Attribution-Non-commercial 4.0 International (http://creativecommons.org/licenses/by-nc/4.0/), which permits use, distribution, and reproduction in any medium, provided the original work is properly cited, the use is non-commercial and is otherwise in compliance with the license. 


\section{INTRODUCTION}

The rising level of sports games competitions demands a lot from athletes; therefore, rational supervision of a training process, understood as a constant increase in athletes' intellectual, physical and motor abilities, becomes an absolute necessity at present. Expectations of practitioners of team sports games are huge. On the one side, coaches expect working out objective criteria of the assessment of players' efficiency of action enabling a comparison of results achieved by players to standards; on the other hand, athletes want to know strengths and weaknesses of their sports competence and to compare the level of their own achievements with results of their opponents and thus have a clear purpose of a training program.

One of the control tools and evaluation of predispositions to game-play are motor tests. They are basic means of training control, but only when scientifically authenticated in the aspects of objectivity, reliability and accuracy $[1,2]$. They cannot be applied incidentally, and an athlete's sex, age and training experience should be taken into consideration in the process of selection $[3,4,5,6]$. So far standards of judgment of soccer competence at individual stages have not been worked out. Hence the objective of this research was to work out appropriate test tasks which would serve for the assessment of the level of unique abilities and motor skills in 17-year-old junior athletes practicing soccer.

\section{MATERIAL AND METHODS}

The research was conducted in sports facilities at the end of April and the beginning of May of 2012. 16 athletes, aged 17 years, from the Centre of Sports Training for Youth in Gdansk were selected for the research. They were competitors of various soccer clubs from the Pomeranian province. Data were collected as part of an athlete monitoring program. Ethics approval for this study was granted by the Scientific Board of the Faculty of Physical Education and written consent parental was received prior to all experimental procedures. At the first stage, on the basis of the analysis of the said issue in literature and the authors' own coaching experience, 13 test tasks were made, modified and selected. The following efficiency tests were determined:

- $1000 \mathrm{~m}$ (from the set of ICSPFT tests) [7], $30 \mathrm{~m}$ runs and "envelope run" (from the set of INKF tests) [8],

- long jump without run up (from the set of EUROFIT tests) [9],

- standing on one leg and keeping the ball on foot and juggling on the head while standing on one leg,

- "envelope" dribbling, juggling on the head and foot in turns (from the Motor Coordination Tests) [10],

- a throw-in for distance, kick of the ball for distance (modification of the test) [11],

- passing and trapping the ball with the sole of a foot against a small bench from a 3-meterdistance with the right and the left leg in turns for five times [12],

- shots into the outlined sector of the goal (the authors' own proposal),

- test-game $1 \times 1$ [13]. 
In the next stage reliability and accuracy of chosen test tasks were examined. Applying the test-re-test method (two two-day test sessions every second day, in the same place and at the same time of the day), the reliability and diversity of results achieved in efficiency tests by the examined players were checked. Pearson's correlation coefficient was calculated. The accuracy of the examined test tasks was evaluated on the basis of a criterion of internal accuracy tests $[14,15,16]$. For this purpose three coaches independently assessed the efficiency of the subjects in a classified game; Szwarc's observation sheet for the assessment of action was used. For all players ranking positions were established, and they were correlated with scores of motor tests converted into ranks. Spearman's Rank Correlation Coefficients were calculated [17]. At the last stage of research a linear regression equation was determined. With the application of Hellwig's algorithm of the optimal choice of explaining variables, four test tasks implementing most information on assessing the subjects were determined [18].

\section{RESULTS}

\section{Reliability}

Pearson's correlation coefficient showed (Table 1) that all the accomplished test tasks met the required conditions of reliability. The strength of correlation in all efficiency tests was statistically significant at the level of $\mathrm{p}<0.001$. Reliability indices fluctuated from 0.654 to 0.922 .

Table 1. Reliability rates of test tasks in the test-re-test method

\begin{tabular}{ll}
\hline Test tasks & $\begin{array}{c}\text { Pearson's correlation } \\
\text { coefficient }\end{array}$ \\
\hline 1000 m run & $0.815^{* * *}$ \\
\hline 30 m run & $0.845^{* * *}$ \\
\hline Jump performed on the spot & $0.871^{* * *}$ \\
\hline “Envelope Run" & $0.701^{* * *}$ \\
\hline Juggling on the head while standing on one leg & $0.692^{* * *}$ \\
\hline Standing on one leg and keeping the ball on foot & $0.851^{* * *}$ \\
\hline Throw-in for distance & $0.922^{* * *}$ \\
\hline Trapping the ball with a sole of the foot against a small bench & $0.721^{* * *}$ \\
\hline Shots at a target & $0.682^{* * *}$ \\
\hline Kicking the ball for distance & $0.901^{* * *}$ \\
\hline “Envelope” dribbling & $0.736^{* * *}$ \\
\hline Juggling on the head and foot in turns & $0.654^{* * *}$ \\
\hline Test-game 1x1 & $0.712^{* * *}$ \\
\hline p $<0.001$ & \\
\hline
\end{tabular}




\section{ACCURACY}

To examine accuracy, a criterion of a coach ranking list was applied. For this purpose three independent coaches observed competitors in a classified game-play (3 matches). Data of efficiency of particular actions were recorded on a special observation sheet. The total sum of the results placed the athletes in a ranking list. A consensus of opinions among the experts amounted to $80 \%$, and such correlation coefficients are assumed to be sufficient [19]. Table 2 shows that the correlation coefficient between individual test tasks varied very much.

Apart from juggling on one leg, all other tests met the requirements of statistical significance. Spearman's Rank Correlation Coefficients ranged from 0.10 to 0.92 . The lowest values $(\mathrm{p}<0.05)$ were achieved in: a throw-in for distance (0.26), shots at a target (0.32) and test-game $1 \times 1(0.38)$; the highest values (meeting the requirements of statistical significance at the level of $\mathrm{p}<0.001)$ were gained in: "envelope" dribbling (0.92), 30m run (0.74) and passing and trapping the ball against a small bench (0.69).

Table 2. Spearman's Rank Correlation Coefficients according to the criterion of internal test accuracy

\begin{tabular}{lc}
\hline Test tasks & $\begin{array}{c}\text { Spearman's correlation } \\
\text { coefficient }\end{array}$ \\
\hline $1000 \mathrm{~m}$ run & $0.67^{* * *}$ \\
$30 \mathrm{~m}$ run & $0.74^{* * *}$ \\
\hline Jump performed on the spot & $0.64^{* * *}$ \\
\hline "Envelope Run” & $0.57^{* * *}$ \\
\hline Juggling on the head while standing on one leg & 0.10 \\
\hline Standing on one leg and keeping the ball on foot & $0.61^{* * *}$ \\
\hline Throw-in for distance & $0.26^{*}$ \\
\hline Passing and trapping the ball with a sole of the foot against & $0.69^{* * *}$ \\
\hline Shots at a target & $0.32^{*}$ \\
\hline Kicking the ball for distance & $0.68^{* * *}$ \\
\hline "Envelope” dribbling & $0.92^{* * *}$ \\
\hline Juggling on the head and foot in turns & $0.52^{* * *}$ \\
\hline Test-game $1 \times 1$ & $0.38^{*}$ \\
\hline
\end{tabular}

$* \mathrm{p}<0.05 * * \mathrm{p}<0.01 * * * \mathrm{p}<0.001$

\section{THE FINAL TEST}

The research proved that almost all suggested tests fulfil basic criteria regarding reliability and accuracy. An exception was in the case of the efficiency test of juggling on a leg, in which the value of rank correlation did not reach statistical significance. However, the control of players' efficiency on the basis of 12 test tasks would be unreasonable from the organizational and economical point of view (too much support equipment, long time of taking measurements); therefore, based on statistical analysis, a set of four 
test tasks was selected. The following procedure was applied. Individual rates of information capacity for every test task were calculated by Hellwig's method and statistical Microfit program (version 5.0). Considering their values and the correlation relationship it was decided (Table 3) that the following test tasks should be included in an optimal model: "envelope" dribbling, $30 \mathrm{~m}$ run and passing and trapping the ball with a sole of the foot against a small bench from a 3-meter-distance and finally kicking the ball for distance.

Table 3. Places in individual physical efficiency tests and in the classified game play in ranking classification (in ranking points).

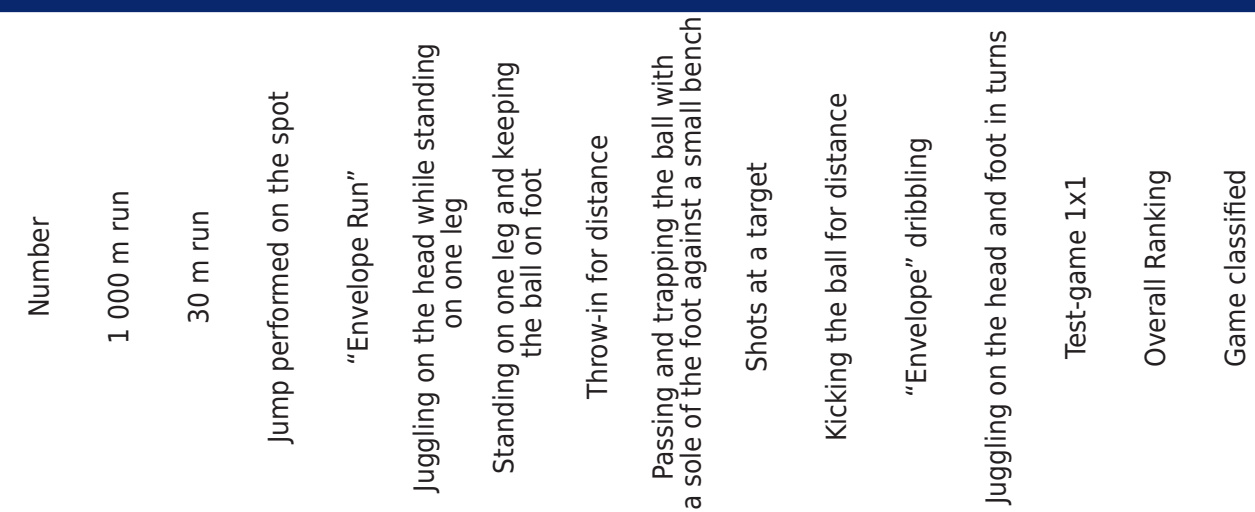

\begin{tabular}{cccccccccccccccc}
\hline 1. & 15 & 14 & 14 & 3 & 8 & 13 & 7 & 13 & 13 & 7 & 11 & 12 & 3 & 11 & 10 \\
2. & 16 & 10 & 5 & 12 & 11 & 11 & 6 & 12 & 13 & 14 & 13 & 10 & 11 & 12 & 13 \\
\hline 3. & 6 & 1 & 9 & 2 & 13 & 4 & 2 & 8 & 6 & 7 & 7 & 12 & 16 & 6 & 6 \\
\hline 4. & 10 & 11 & 11 & 14 & 4 & 3 & 15 & 11 & 14 & 13 & 12 & 16 & 15 & 14 & 12 \\
\hline 5. & 4 & 6 & 7 & 7 & 8 & 15 & 9 & 5 & 6 & 4 & 6 & 6 & 2 & 4 & 9 \\
\hline 6. & 3 & 5 & 6 & 13 & 16 & 5 & 14 & 3 & 1 & 5 & 5 & 14 & 6 & 5 & 2 \\
\hline 7. & 11 & 4 & 8 & 5 & 9 & 8 & 5 & 15 & 11 & 1 & 9 & 8 & 6 & 7 & 7 \\
\hline 8. & 1 & 7 & 3 & 6 & 4 & 1 & 8 & 4 & 2 & 8 & 4 & 4 & 8 & 3 & 4 \\
\hline 9. & 13 & 16 & 16 & 11 & 12 & 12 & 13 & 16 & 7 & 16 & 16 & 14 & 12 & 15 & 16 \\
\hline 10. & 12 & 15 & 15 & 15 & 14 & 16 & 16 & 14 & 11 & 15 & 15 & 6 & 14 & 15 & 15 \\
\hline 11. & 4 & 2 & 1 & 1 & 11 & 6 & 4 & 2 & 4 & 3 & 1 & 1 & 1 & 1 & 1 \\
\hline 12. & 9 & 3 & 2 & 4 & 2 & 2 & 11 & 1 & 4 & 2 & 3 & 4 & 5 & 2 & 8 \\
\hline 13. & 7 & 8 & 12 & 8 & 6 & 7 & 12 & 7 & 16 & 11 & 2 & 4 & 9 & 9 & 3 \\
\hline 14. & 8 & 12 & 4 & 10 & 16 & 10 & 1 & 9 & 16 & 9 & 8 & 8 & 13 & 10 & 6 \\
\hline 15. & 16 & 13 & 11 & 16 & 5 & 14 & 3 & 10 & 9 & 12 & 14 & 15 & 10 & 13 & 14 \\
\hline 16. & 2 & 9 & 10 & 9 & 2 & 9 & 10 & 6 & 9 & 10 & 10 & 10 & 4 & 8 & 11 \\
\hline
\end{tabular}

Equation of regression showing numerical relations between variables looks as follows (Table 4):

$\mathrm{Y}=1.11 \mathrm{x}_{1}+0.037 \mathrm{x}_{2}-0.27 \mathrm{x}_{3}+0.001 \mathrm{x}_{4}$

where: a dependent variable Y means the expert's assessment of a classified game-play, and independent variables are: $\mathrm{x}_{1}$ - "envelope" dribbling, $\mathrm{x}_{2}-30 \mathrm{~m}$ run, $x_{3}$ - passing and trapping the ball with a sole of the foot against a small bench from a 3-meter-distance, $\mathrm{x}_{4}$ - kicking the ball for distance. 
Table 4. Individual rates of information capacity in test tasks by Hellwig (1969)

\begin{tabular}{|c|c|c|c|}
\hline \multicolumn{4}{|c|}{ Ordinary Least Squares Estimation } \\
\hline \multicolumn{4}{|c|}{$\begin{array}{l}\text { Dependent variable is Y } \\
16 \text { observations used for estimation from } 1 \text { to } 16\end{array}$} \\
\hline Regressor & Coefficient & Standard Error & T-Ratio (Prob) \\
\hline $\mathrm{X}_{1}$ & 1.1086 & .24824 & $4.4658(.001)$ \\
\hline$x_{2}$ & .037268 & .21033 & $17719(.863)$ \\
\hline$x_{3}$ & -.27425 & .20080 & $-1.3658(.199)$ \\
\hline$X_{4}$ & .0019812 & .18707 & $.010591(.992)$ \\
\hline $\mathrm{A}$ & 1.1369 & 1.1738 & $.96855(.354)$ \\
\hline \multicolumn{2}{|c|}{ R-Squared .86713} & \multicolumn{2}{|c|}{ R-Bar-Squared .81882 } \\
\hline \multicolumn{2}{|c|}{ S.E. of Regression 2.0084} & \multicolumn{2}{|c|}{ F-Stat. $\quad F(4,11) 17.9471(.000)$} \\
\hline \multicolumn{2}{|c|}{ Mean of Dependent Variable 8.5625} & \multicolumn{2}{|c|}{ S.D. of Dependent Variable 4.7183} \\
\hline \multicolumn{2}{|c|}{ Residual Sum of Squares 44.3698} & \multicolumn{2}{|c|}{ Equation Log-likelihood -30.8628 } \\
\hline \multicolumn{2}{|c|}{ Akaike Info. Criterion -35.8628 } & \multicolumn{2}{|c|}{ Schwarz Bayesian Criterion - 37.7943} \\
\hline \multicolumn{4}{|c|}{ DW-statistic 2.4259} \\
\hline
\end{tabular}

The proposed set of test tasks forms an optimal combination of efficiency tests showing the efficiency of competitors' activities in a classified game play in $86.7 \%$. It is assumed that such a percentage is satisfactory and brings significant information about the explained variable [20].

\section{DISCUSSION}

A test can be regarded as a reliable tool for monitoring only if it is previously subjected to scientific verification in terms of standardization, reliability and validity $[19,20]$. We proposed special physical fitness tests which underwent such a procedure. Detailed instructions how to conduct them were developed. In reliability studies, using a test-re-test method, Pearson correlation coefficients for all the test tasks ranged from 0.654 to 0.922 . It means that all the tasks met the reliability requirement $(\mathrm{p}<0.001)$. The lowest values of reliability were achieved in attempts of assessing technical skills (juggling a ball, "envelope" dribbling, scoring goals), and the highest ones in the tests for estimating the level of physical abilities (speed, endurance, rate of power development) and the simplest technical skills (throw-in for distance, kicking the ball). Similar relationships were found in their studies by Kutlu et al. [21]. Thus, we can say that the easier the motor task to perform, the higher the accuracy with which the test measures what it is supposed to. This information is extremely important for trainers. The results achieved in tests by the athletes were correlated with their efficiency of game classified according to the criterion of external accuracy of tests $[14,16]$. Research shows that the strength of correlation between results achieved by the players in various test tasks with their skills in the game was very diverse. However, except for only one attempt, all tests complied with the requirements of statistical significance. Values of accuracy indices of the test tasks ranged from 0.26 to 0.92 . The lowest value was achieved in the test of throw-in for distance, scoring the goal and test-game $1 \times 1(p<0.05)$ and the highest one in "envelope" dribbling, $30 \mathrm{~m}$ run and passing and trapping the ball with a sole of the foot against a small bench $(p<0.001)$. It is difficult to explain the cause of this situation. Other researchers $[4,8]$ found considerable variation of values of 
accuracy indices. Thus, using statistical analysis, four-task sets of tests were chosen for the final test. The selected set of tests tasks creates the optimal combination of selected components of physical fitness mapping in $86.7 \%$ of the examined football players' ability to play. Such a percentage is satisfactory, because it brings essential information about the dependent variable [17, 20]. Moreover, the indicated series of tests comprises the most important abilities and motor skills for a footballer - striking, reception and dribbling the ball as well as locomotion speed at the most characteristic distance for football. It is worth adding that the test tasks selected by statistical analysis achieved the highest indices of reliability and accuracy. In the next research which is selected and checked with regard to standardization, we will verify reliability and accuracy of the set of task tests among footballers of other age categories.

\section{CONCLUSION}

The optimal set of tests describing in $86.7 \%$ the efficiency of activity of 17-year-old competitors in game-play should contain the following efficiency tests: "envelope" dribbling, 30m run, passing and trapping the ball with a sole of the foot against a small bench from a 3-meter-distance and kicking the ball for distance. Results of special physical fitness tests should be treated as important information about young athletes' special physical efficiency, closely interdependent with the effectiveness of their activity in a classified game-play, but only when the tests themselves have previously been scientifically proved.

\section{REFERENCES}

[1] Impellizzeri FM, Marcora SM. Test validation in sport physiology: Lessons learned from clinimetrics. Int J Sport Physiol Perform. 2009;4:269-277.

[2] Aandstad A, Simon EV. Reliability and validity of the soccer specific INTER field test. J Sci. June 2013;31(13):1383-1392.

[3] Stula A. Research into assessment of speed or endurance predisposition of 12 and 13 year old schoolboys in the context of selection to suitable sports disciplines. In: Merica M, editor. Vedecke Prace na Podporu Projektov Vega. Bratislava: STU; 2008, 146-150.

[4] Sporis G, Jukic I, Milanovic L, Vucetic V. Reliability and factorial validity of agility tests for soccer players. J Strength Condition Res. March 2010;24:679-686.

[5] Barker AR, Armstrong N. Exercise testing elite young athletes. Med Sport Sci. 2011;56:106-25.

[6] Mendez-Villanueva A, Buchheit M. Football-specific testing: Adding value or confirming the evidence? J Sport Sci. June 2013;31(13):1503-08.

[7] Larson LA. Editor. Fitness, Health, and Work Capacity: International Standards for Assessment. New York, USA: McMillan Publ. Co; 1974.

[8] Ulatowski T. (Wybrane metody obserwacji i oceny walki i wspolzawodnictwa sportowego [Selected methods of observing and evaluating the fighting and athletic competition]. In: Ulatowski T, editor. Zastosowanie metod naukowych na potrzeby sportu [Application of scientific methods to the needs of sport]. Warsaw: Estrella; 2002, 228-244. Polish.

[9] Eurofit. Handbook for the Eurofit tests of Physical Fitness. Rome: Council of Europe; 1988.

[10] Ljach W, Witkowski Z. Koordynacyjne zdolnosci motoryczne w pilce noznej [Coordination motor skills in football. Warsaw: Main Sports Centre (COS); 2004. Polish.

[11] Talaga J. Sprawnosc fizyczna ogolna. Testy [General physical fitness. Tests]. Poznan: Zysk i spolka; 2004. Polish.

[12] Weise D, Pfaff B. Talente Fordern. Frankfurt/Main: DFB; 2002.

[13] Szwarc A. Sprawnosc dzialania w wybranych fragmentach zespolowej gry sportowej na przykładzie pilki noznej [Efficiency of action in selected areas of team sports game (for example of soccer)]. Gdansk: Gdansk University of Physical Education and Sport; 2007. Polish.

[14] Khan SB. An internal criterion of test validity. Psychology Report. June 1968;22(3):1145-1152.

[15] Smith GT, Fischer S, Fister SM. Incremental validity principles in test construction. Psychological Assessment. Dec 2003;15(4):467-477.

[16] Brzezinski J. Metodologia badan psychologicznych [The methodology of psychological research]. Warsaw: The National Scientific Publisher; 2010. Polish.

[17] Snedocor GW, Cochran WG. Statistical methods, eight edition. Iowa: Iowa State University Press; 1989. 
[18] Hellwig Z. Problem optymalnego wyboru predykant [Problems of optimal selection explanatory variables]. Statistical Review. 1969:3-4:221-237. Polish.

[19] Kline P. A handbook of test construction. London: Methuen; 1986.

[20] Rygula I. Proces badawczy w naukach o sporcie [The research process in science of sport]. Katowice: Academy of Physical Education; 2004. Polish.

[21] Kutlu M, Yapici H, Demirkan E, Yulmaz A. Reliability and Validity of New Tests on Agility and Skill for Children Soccer Players. Central Eur J Sport Scie Med. Dec 2014;6(2):5-12. 